\title{
The Impact of Crisis Management on Employee's Performance in the Yemeni Oil and Gas Industry
}

\author{
Ghadah Mansoor Al-Ariki ${ }^{1}$, Mohammed Saleh Al-Abed ${ }^{2}$ \\ ${ }^{1}$ Lebanese International University, Sana'a, Yemen \\ ${ }^{2}$ Impact Research Center, Sana'a, Yemen \\ Correspondence: Ghadah Mansoor Al-Ariki, Lebanese International University, Sana'a, Yemen. \\ E-mail: ghadah.alariki@gmail.com \\ Received: January 2, 2021 \\ Accepted: January 22, 2021 \\ Online Published: February 17, 2021 \\ doi: 10.48110/joi.v2i1.17 \\ URL: https://doi.org/ 10.48110/joi.v2i1.17
}

\begin{abstract}
This study examines the impact of crisis management on employee's performance in the Yemeni oil and gas industry. Crisis management was measured by two dimensions; crisis preparedness and crisis prevention. Whereas employee's performance was measured by three diminutions; task performance, adaptive performance, and contextual performance. The study uses a quantitative approach. Questionnaires were used to collect data from 6 oil and gas companies. The sample comprises of 351 participants, out of which 268 (74.23\%) responded. The reliability of the instruments was examined and the results of the Cronbach's Alpha was .906, indicating an excellent reliability. The results of regression analysis reveal that crisis management as the whole independent variable has a significant impact on employee's performance as dependent variable. Furthermore, the results of regression analysis reveal that there is a significant relationship between crisis management and employee's performance in terms of crisis preparedness, crisis prevention, and employee's performance. Essentially, crisis appraisals should include testing as an integral aspect of planning for any eventuality. Ultimately, organizations should install communication units or structures and ensure employees are trained well. This study has made some recommendations for oil and gas companies.
\end{abstract}

Keywords: Employee's Performance, Crisis Management, Crisis Preparedness, Crisis Prevention, Oil and Gas companies, Yemen.

\section{Introduction}

Bah and Fang (2015) asserted that high productivity in a company is dependent on the performance of employees. Essentially, the success of any business is influenced by the employee smart and effective performing of tasks towards realizing the corporate goals (Bundy, Pfarrer, Short, \& Coombs, 2016). The studies of employee's performance are connected with some different variables. Organizations that have the capacity to comprehend the effect of employees' performance are better placed to manage their throughput (Saddam \& Abu Mansor, 2015). Fundamentally, productivity comes with a ripple effect in a workplace setting, whereby consistent productivity and corporate culture set precedence for other employees (Kiruja \& Mukuru 2013).

According to Saddam and Abu Mansor (2015), oil and gas industry is the main pillar of economic and social development of Iraq. In addition, Iraq has been affected by sanctions and wars that affected the retention of skilled human resources. For that reason, the authors alleged that productivity of this industry is determined by the quality of human capital. Subsequently, there is an association between employee and corporate performance. In this study, the researcher discusses the three dimensions to measure the employee's performance, which include task performance, adaptive performance and contextual performance, as based on the study of Pradhan and Jena (2017). 
However, this study sheds light on the crisis management due to the catastrophe situation in Yemen leading to some companies leaving the country. The crisis management is defined as a three-fold process utilized in preventing a conflict from happening or by trying to scale down its impact (Bujak \& Topolski, 2015). Williams et al. (2017) suggested that crisis management is the action of developing and executing a business strategy, which can be adopted easily under different circumstances. While crisis is linked to the unexpected and collateral damages that come with it, organizations can avoid colossal losses and enhance productivity if they implement the best approach in managing the crisis (Williams et al., 2017).

An effective crisis management plan is a premium for the company in terms of monetary gains not simply by averting the crisis and avoiding the loss but rather by an incentive to investors. Moreover, crisis management works as a damage control for organizations. Nonetheless, owing to crisis reproduction, workers are empowered to respond promptly when facing a crisis (Williams et al., 2017). Owing to the unpredictable nature of the world, crisis management skills remain critical especially if organizations have to survive drastic occurrences whether unforeseen or manmade (Boin, Stern \& Sundelius, 2016). At that point, employees that are well trained to manage crises would be better placed to make quick and right decisions, while underpinned by proficient communication in managing the crisis (Boin et al., 2016).

Pre-crisis management involves getting into activities that aim at reducing the probability of occurrence of an incidence. According to Bahadori, Khankeh, Zaboli and Malmir (2015), crisis presentence entails organizational planning tasks, which can involve proper resources to support the already made resources, depending on nature of the crisis. Crisis prevention is a method that puts early warnings and scanning of the identified crisis. This prevention process can entail making audits and scanning through the business environment (Jackson, 2017).

This study focuses on oil and gas companies. However, it is rare to find studies connected with crisis management and employee's performance in oil and gas companies in Yemen. According to Yemen Market Profile (2019), Yemen is a small oil-producing country outside of OPEC. It allows foreign oil companies to exploit its oil fields because of its lack of the necessary capital and technology resources. Before the conflicts in 2014, Yemen was mainly dependent on the already declining oil and gas resources for revenue, accounting for roughly $25 \%$ of its GDP and 65\% of government revenue (Yemen Market Profile, 2019).

Yemen is a low-income nation that experiences daunting long-term problems in order to sustain and develop its economy, according to Yemen Economy (2019). The current conflict has only worsened these problems and brought Yemen's exports to a pause. That in effect, has placed pressure on currency exchange rates, increased inflation, significantly restricted imports of food and fuel, and caused extensive infrastructure harm. Thus, this study is aimed at investigating the influence of crisis management on the efficiency of employees in the oil and gas industry in Yemen.

According to Yemen Economic Monitoring Brief (2018), due to both political and security instability, the restoration of oil and gas industry is difficult to say the least. The escalation of conflict led to foregone fiscal revenues on a massive scale and the departure of foreign operators. It also inflicted large-scale destruction of infrastructure. All these factors have weighed on the speed of an eventual full recovery of the oil and gas sector.

Therefore, this study aims to examine the impact of the crisis management with the two dimensions (crisis preparedness and crisis prevention) on employee's performance in Yemeni oil and gas industry.

\section{Literature Review}

\subsection{Employee's performance}

According to Sharma, Sharma and Agarwal (2016), productivity and success of business establishments is a function of employee's performance. In this context, the efficiency of employee's is important to a company's growth (Sharma et al., 2016). As an outcome, it is important to establish a clear and analytical method to assessing the contribution of a person to the progress of organizations to recognize their strengths and deficiencies and the possible management vulnerabilities that impede excellent results (Sharma et al., 2016). Getting good perspectives into each employee's success level profoundly allows to assess an acceptable plan of action to follow throughout the crisis.

Iqbal et al. (2015) defined employee's performance as the execution of well-defined responsibilities, meeting timelines, employee competency, and the proficiency of undertaking tasks. The authors continued to suggest that different companies require sound leadership approaches that stimulate the employee's performance. In a bid to examine how leadership impact performance, a study by Iqbal et al. (2015) researched a company that manufacture tractors and established how it grapples with issue of employee's performance. Essentially, the inability to innovate was also seen as the reason some companies fail to meet set targets, which leads to low productivity.

A previous study indicated that employee's performance is important when it comes to defining organizational success (Mangkunegara, 2016). Nonetheless, organizations have to put in place good performance measures to 
attain the goals. Furthermore, this research demonstrated that employee's performance consists of staff productivity and behavior in attaining the target outcome (Mangkunegara, 2016). The author also showed how transformational leadership and workplace setting are correlated with positive employee's performance. Additionally, organizations pursue employee's performance to gain competitive edge.

Therefore, transformational leaders lead to positive employee's performance by articulating the organizational visions, intellectual stimulation, setting high performance, and providing the required support (Mangkunegara, 2016). With respect to Mangkunegara (2016), transformational leaders highlight the importance self-development, stimulate workers to creatively think and resolve problems to achieve organizational objectives.

The literature shows that in oil and gas companies, employees play an important role (Edwin, 2015). Nevertheless, firms have overlooked employee training and development programs. Edwin (2015) alleged that training and development enable workers to acquire new skills as well as knowledge to enhance performance.

The literature shows that in oil and gas companies, employees play an important role (Edwin, 2015). Nevertheless, firms have overlooked employee training and development programs. Edwin (2015) alleged that training and development enable workers to acquire new skills as well as knowledge to enhance performance. In addition, the benefits of performance are associated with employee training and development. Therefore, training presents workers with required skills to improve organizational performance. Moreover, training programs allow oil and gas companies to use advanced technologies and respond to the competitive market. Besides, training programs contribute to improved employee productivity as well as job fulfillment, which result in organizational vitality and economic stability (Edwin, 2015). However, the training programs must be consistent with the organizational strategy. Again, the study found that the training should be aligned with organizational tasks.

According to Robescu and Iancu (2016), employee's performance is determined by motivation. Motivation comprises of limits and type of activities that are oriented to the attainment of the target goals. Nonetheless, employee's performance and motivation can be considered as associated concepts. Accomplishment of duties is a motivation and a factor. In this study, the authors allege that employee's performance cannot increase with high levels of motivation particularly if the task is complex (Robescu \& Iancu, 2016). On the contrary, increased levels of motivation have also been attributed to negative performance. This is purely because as high motivation lowers cognition, motivated employees become afraid of failing, an aspect that eventually contributes to lower performance (Robescu \& Iancu, 2016). Furthermore, in organizations, employee's performance is based on different factors including restrictive procedures and workplace environmental aspects such as variability of resources, lighting and noise.

Rui et al. (2017) alleged that the success of oil and gas organizations significantly relies on actual performance and target goals. In addition, the correct measure of employee effectiveness is performance, which can be measured by assessing actual output against the target output. The authors also suggested that to achieve target output, employee's performance standards must be instituted and communicated. On the other hand, the actual output should be measured and analyzed (Rui et al., 2017). Consequently, the study found a strong association between corporate factors including management support, performance feedback, and physical workplace aspects, which lead to improved employee's performance (Rui et al., 2017).

A proper workplace setting is important in terms of lowering the rate of absenteeism hence increased employee's performance. The authors established that organizational factors have strong association with performance (Rui et al., 2017). Poor workplace settings can contribute to psychological and physiological effects that could influence job performance. This indicates that in the oil and gas industry, organizations should recognize the impact of potential workplace factors on employee's performance. Even though high performance can be attributed to technology advancements, organizational culture and workplace environment play an important role in employee's performance.

\subsection{Crisis Management}

Crisis management has been acting as a provision of preplanning of organizational performance and rapid response by acting towards leadership. Information management has been facing crisis in the market due to bad informatics (Christensen et al., 2016). This has been creating critical situation in protecting the organization's reputation. Managing crisis is also geared towards enhancing performance through early threat exposure, mitigation and product life cycle control (Christensen et al., 2016).

Essentially, managing crisis is a phrase employed to rational and methodical way of establishing the context, determining, evaluating, treating, checking and relaying threat relating to any procedure in a manner that enables firms to reduce losses and enhance prospects (Crandall, Parnell, \& Spillan, 2013). Crisis management enhances not just the value of firms, but may also diminish financial distress (Jundt et al., 2015). The purpose of crisis management is to realize the understanding by all stakeholders and arrangement around what the threats really are and how to control the crisis (Bundy et al., 2016). 
According to Mehr and Jahanian (2016), crisis management is a procedure considered when mitigating a crisis with the aim of lessening the negative effect that the crisis can have on the company and stakeholders alike. Since crisis management is a process, it can be clustered into pre-crisis, response mechanism to the crisis and post-crisis. In addition, Bujak and Topolski (2015) defined crisis management as a three-fold process utilized in preventing a conflict from happening or trying to scale down its impact.

Williams et al. (2017) pointed out that crisis management is the activity for developing and executing a business strategy that can be adopted easily when facing a crisis. Occurrences that qualify as crises include natural calamities, terror attacks, power outages, violence, and cybercrimes among others. Bundy et al. (2016) suggested that crisis management is the utilization of methods aimed at helping the organization deal with unexpected events that can affect the smooth running of the organization. Based on the author, a crisis may happen due to

unforeseeable outcomes of some event that could be seen as prospective threat.

Disruptions in oil production due to violence, fires and other mishaps can lead to monumental economic losses and grave hazards to people and the ecosystem (Jundt et al., 2015). The purpose of crisis management is to realize the understanding by all stakeholders and arrangement around what the threats really are and how to control the crisis (Bundy et al., 2016). According to Crandall et al. (2013), experience allows companies to react to the rapid, short-range and long shock that is necessary for the company's regular activity or to handle the market. The major crisis management mechanism in the oil and gas sector usually continues with pre-crisis events, including preparation and mitigation practices (Crandall et al., 2013).

\section{H1: Crisis management has a significant impact on employee's performance.}

The global world is marked by dramatic transitions that trigger different kinds of organizational and employee efficiency crises (Anitha, 2014). The willingness of businesses and workers to respond to these changes is negatively affected due to the high pace of change and uncertainty (Anitha, 2014). The organization will gain operating productivity during the transitions, as the skills learned through the transition build trust in workers about their abilities to achieve organizational objectives (Anitha, 2014). Crisis management may potentially have a serious impact on workers, specifically if a company employs an unsuccessful plan to reverse the crisis (Pop, 2017). As such, crisis management must still be constructive and provide management with the ability to formulate effective tactics that will motivate workers to step on in anticipation of critical circumstances that are imminent (Pop, 2017).

Organizations that have proper crisis management programs have a higher probability of having lower employee turnover rates. Employee turnover negatively influences the activities of the organization, as the organization does not have someone to educate new employees on the culture of the organization (Raufflet, Cruz \& Bres, 2014). Furthermore, the organization has to incur more costs to ensure that the employees remain within the organization by increasing their pay and that there is cooperation from all the employees. Employees are also likely to find it difficult to get into the organization targets and stresses, as they are unable to ensure that all activities run smoothly and effectively.

In addition, the contact deficiencies during the deep-water horizon spill by BP were discussed by De Wolf and Mejri (2013). BP has unable to provide an accurate account of its protection policies and practices since the beginning of the crisis. The executives made the first of their numerous communication mistakes (De Wolf \& Mejri, 2013). In addition, the organization invested in divisive politics with multiple partners and worked on a public advertising drive to protect its tarnished image (De Wolf \& Mejri, 2013). Such coordination problems have had a detrimental effect on the success of the company's personnel. Some of them were shot and eventually charged with murder, which greatly lowered the morale of workers and consequently had a detrimental influence on their results (De Wolf \& Mejri, 2013).

Management typically hires talented workers and provides instruction to provide them with the necessary expertise required to handle the duties efficiently in order to compact a situation affectively. Likewise, crisis management culminates in promoting core values that help a business to meet strategic goals. Despite these shifts, oil and gas producers are experiencing several global crisis-related challenges. Because of the numerous conflicts witnessed in oil consuming countries, these issues are synonymous with political turmoil.

As an outcome, the assessment of the output of workers in oil and gas firms since the recession has remained a major problem that several reports have not discussed. This study therefore fixes the gap by suggesting concrete techniques to be employed in the Yemeni oil and gas sector to eliminate several commonly witnessed instances of crisis.

\subsubsection{Crisis Preparedness}

An organization that does not have a crisis management plan and an ability of tweeting within ten minutes of occurrences of a crisis is not ready to compete effectively in the technological world. Pre-crisis management 
involves getting into activities that aim at reducing the probability of occurrence of an incidence (Comyns, 2016). Bundy et al. (2016) suggested that crisis preparedness organizational pre-crisis activities also include operational preparation practices, which include placing in position enough capacity to enhance all the exercise, estimating needs, and supporting resources, depending on the type of the crisis.

The second phase in pre-crisis preparedness training is to set up programs and guides to help the practice in crisis management. Crandall et al. (2013) indicated that systems involve the structures put in place to alert the

organizations about crisis. For instance, early warning systems and control measures help the organization to monitor and respond to the crisis. Dörry and Schulz (2018) suggested that crisis hampers the company activities and systems. Nonetheless, the authors indicated that crisis comes with perilous effects that may derail the productivity aspect and damage the company's stature and financial portfolio. However, as a move towards successful crisis management, the research did not provide a tangible roadmap to the design of the programs and guides.

Thirdly, with respect to organizational preparedness in pre-crisis operations, Jaques (2007) claimed that preparation and exercises need to be considered. Previous literature also demonstrated that in crisis preparedness, training helps the employees to test procedures in place (Edwin, 2015). Essentially, they are provided with manuals and training to learn the adaptability and agility of the systems. Jaques (2007) argued that simulation exercises are important as they present employees with the skills to manage potential crisis. Furthermore, crisis preparedness focuses on exercises and activities that help the employees learn about their workplace setting and real simulations.

\section{H1a: Crisis preparedness has a significant impact on employee's performance.}

\subsubsection{Crisis Prevention}

Crisis prevention is a function of early warning signs that should be evaluated to comprehend the message being communicated (Eisner et al., 2019). The ability to map and identify the problem acts as the first step for managing the crisis. Nonetheless, the authors also suggested that part of crisis prevention is the ability to manage employee anxiety, which precludes them from harm, especially when the crisis manifests a terror attack or fire outbreak (Eisner et al., 2019). The crisis reduction component is related to the introduction of early alerts and scanning as part of pre-crisis management practices. The method includes auditing and scanning the atmosphere and policies to ensure that strategic practices are followed for improved performance, which strengthens the framework of corporate diligence (Andrianopoulos, 2015).

In the pre-crisis crisis reduction analysis, the second component is the challenge and risk control inside the practices (Jaques, 2007). The phase includes recognizing, prioritizing and implementing effective plans to address the challenges of future occurrences (Pangarkar, 2016). The corporation recognizes the future threats and establishes an effective plan to be used in the case of a business incident (Pangarkar, 2016).

The last step in crisis prevention in the pre-crisis activities is the emergency response. Usually, the component includes personnel training exercises, making adequate paperwork to facilitate emergency management, coupled with the appropriate system that operates together to handle the incident (Taneja et al., 2014). Most crises in the oil and gas sector are caused by emergencies, according to Coombs (2014). Therefore, a consistent structure and plan to manage them for productivity needs to be developed. Businesses ought to make it a habit to curtail the opportunity for change or control the occurrence of emergencies.

\section{H1b: Crisis prevention has a significant impact on employee's performance.}

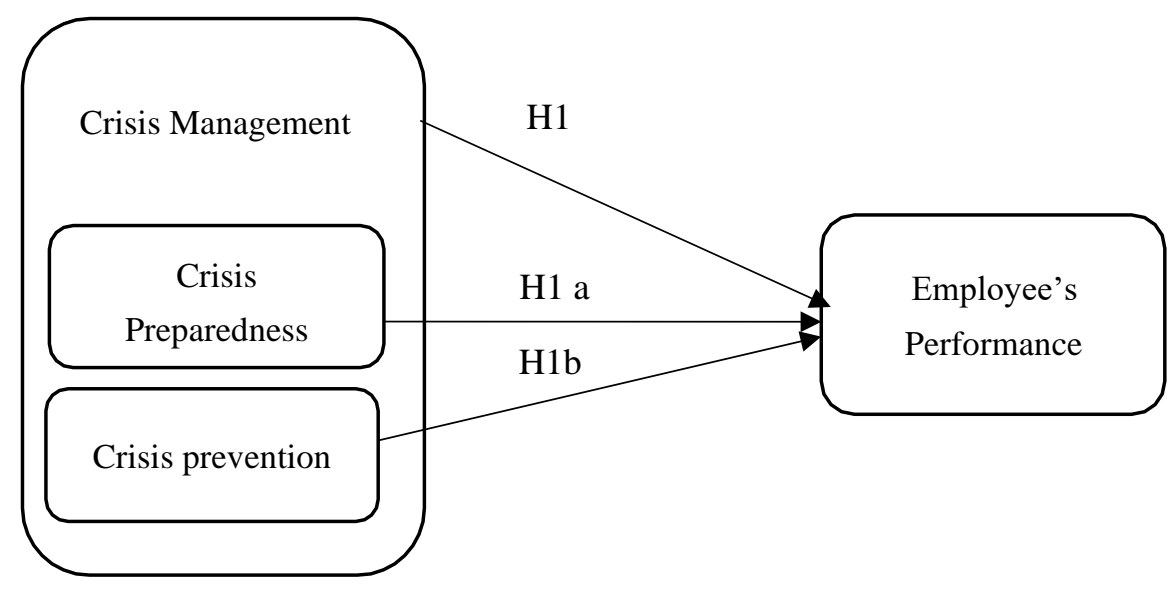

Figure 1. Conceptual Framework 


\section{Methods}

For the purpose of achieving the objective of this study, a quantitative research approach was employed and the data was collected from the employees of the Yemeni oil and gas industry through questionnaires. The measurement of crisis management and its two dimensions; crisis preparedness and crisis prevention, were adapted from Bilić, Pivčević and Čevra (2017), Renschler et al. (2015), Cronin (2015), and Özdemir (2010). Seven questions were used for each dimension. Three dimensions for measuring employee's performance, which include task performance, adaptive performance and contextual performance as dependent variable, were adapted from Pradhan and Jena (2017). Eighteen questions were used to measure the employee's performance. Based on the statistics published by the republic of Yemen, Ministry of Oil and Mineral, General Department of Yemenization (2014), the total number of oil and gas companies is six (Petro-Masila, Safer, Jannah Hunt, Calvalley, OMV and YLNG), and the total number of the employees is 4339 , which is the targeted population of this study. According to the sampling table proposed by Krejcie and Morgan (1970), and since the target population is 4339, the sample size of this research is 351 . The random sampling method was used in order to select the respondents from the targeted Yemeni oil and gas companies. The Cronbach's Alpha is .906, which is an excellent reliability. This means that the reliability scale used in this study is highly reliable or consistent.

\section{Findings}

A survey questionnaire was sent to 351 employees. The total surveys collected back was 268 out of 361 and they were valid. Therefore, an overall response rate of $74.23 \%$ was obtained. Frequency analysis was used in order to show the characteristics of the respondents. The highest participation rate was scored by Petro- Mesial with 38\%, and the lowest participation rate was scored by Calvally with only $2 \%$ participation rate. Results show that the most respondents were male with a total number of $229(85 \%)$; and only $39(15 \%)$ of the respondents were females. The employees' age ranging from 30-40 scored the highest frequency with $156(58 \%)$ and only 6 respondents (2\%) who's aged under 30 .

The educational attainment of employees in oil and gas companies. Bachelor degree scored the highest rate with 172 (64\%) participation. The Master's degree has 68 (25\%) participation. The Diploma has 24 (9\%) participation. The least frequency category is the PHD, which has only 4 (2\%) participation. Regarding the position of the employees in oil and gas companies. The non-managerial staff has the highest rate with 107 (40\%) participation. The first line manager has 83 (31\%) participation. The middle manager has 64 (24\%) participation. The top manager has 14 (5\%) participation. Regarding the experience of the employees in oil and gas companies, the results show that the employees' experience of over 10 years has highest score with $173(65 \%)$ participation. The 6-10 years of experience range has $81(30 \%)$ participation. The range of $2-5$ years of experience has $13(5 \%)$ participation. The range of less than 2 years has only 1 participant.

Descriptive statistics was performed for the variables and dimensions of the study. As shown in Table 1, the descriptive statistics of the 7 items of the crisis preparedness. The items are explained from the highest to the lowest mean. The results reveal that the participants agreed with Item 1 ("We have developed plans and procedures for potential crisis situations"), with a mean of 3.82, and a standard deviation of .96. The participants least agreed with Item 7 ("A details crisis management manual is in place"), with a mean of 3.40, and a standard deviation of 1.14 .

Table 1. Descriptive Statistics of Crisis Preparedness

\begin{tabular}{llcc}
\hline \multicolumn{1}{c}{ Items } & Mean & $\begin{array}{c}\text { Std. } \\
\text { Deviation }\end{array}$ \\
\hline 1 & We have developed plans and procedures for potential crisis situations & 3.82 & .96 \\
2 & Crisis team(s) for potential crisis situations are defined & 3.75 & .92 \\
3 & Crisis teams are informed about their duties and responsibilities in case of crisis & 3.67 & 1.02 \\
4 & The Company has a database with potential crisis situations & 3.66 & .96 \\
5 & The Staff in my company is trained to handle crisis situations & 3.65 & .92 \\
6 & The spokespersons in potential crisis are defined and known & 3.53 & 1.01 \\
7 & A details crisis management manual is in place & 3.40 & 1.14 \\
& Crisis Preparedness & $\mathbf{3 . 6 7}$ & $\mathbf{0 . 9 9}$ \\
\hline
\end{tabular}


When it comes to crisis prevention, Table 2 shows the descriptive statistics results. The results indicate that the participants most agreed with Item 1 ("If my company gets into a serious crisis, I would still get paid until we could reopen ") with a mean of 3.59, and a standard deviation of .90. The participants least strongly agreed with Item 7 ("If my company gets into a serious crisis, the employees are still covered by company's employee benefits'"), with a mean of 3.15, and a standard deviation of 1.01 .

Table 2. Descriptive Statistics of Crisis Prevention

\begin{tabular}{rlrr}
\multicolumn{1}{c}{ Items } & Mean & $\begin{array}{c}\text { Std. } \\
\text { Deviation }\end{array}$ \\
\hline $1 \quad \begin{array}{l}\text { If my company gets into a serious crisis, I would still get paid until we could } \\
\text { reopen. }\end{array}$ & 3.59 & .90 \\
2 & $\begin{array}{l}\text { My company views crisis management readiness as a corporate goal priority } \\
\text { If my company gets into a serious crisis, I would have the data I need to do my }\end{array}$ & 3.51 & 1.01 \\
$3 \quad \begin{array}{l}\text { job backed up at a remote site } \\
\text { In the event of an emergency or disaster, I am familiar with my company's plan } \\
\text { to continue operations from another location }\end{array}$ & 3.48 & 1.08 \\
5 & 3.42 & .91 \\
6 & $\begin{array}{l}\text { If my company gets into a serious crisis, I will still have my job } \\
\text { If my company gets into a serious crisis, I would still be covered by my }\end{array}$ & 3.23 & 1.06 \\
$\begin{array}{l}\text { company's employee benefits } \\
\text { Crisis Prevention }\end{array}$ & 3.15 & 1.01
\end{tabular}

Table 3 shows the descriptive statistics of the employee's performance. About 18 items were examined and the results indicate that the participants strongly agreed with Item 1 ("I used to extend help to my co-workers when asked or needed.") with a mean of 4.45, and a standard deviation of .60.). The statistics show that the item 18 least strongly ("I used to lose my temper when faced with criticism from my team members"), scored a mean of 2.51, and a standard deviation of .94 .

Table 3. Descriptive Statistics of Employee's Performance

\begin{tabular}{|c|c|c|c|}
\hline & Items & Mean & $\begin{array}{c}\text { Std. } \\
\text { Deviation }\end{array}$ \\
\hline 1 & I used to extend help to my co-workers when asked or needed & 4.45 & .60 \\
\hline 2 & I used to maintain high standard of work & 4.35 & .79 \\
\hline 3 & $\begin{array}{l}\text { I always believe that mutual understanding can lead a viable solution in } \\
\text { organization }\end{array}$ & 4.35 & .74 \\
\hline 4 & $\begin{array}{l}\text { I communicate effectively with my colleagues for problem solving and decision } \\
\text { making }\end{array}$ & 4.33 & .65 \\
\hline 5 & I used to complete my assignments on time & 4.32 & .74 \\
\hline 6 & I used to praise my co-workers for their good worker & 4.32 & .66 \\
\hline 7 & I know I can handle multiple assignments for achieving organizational goals & 4.27 & 69 \\
\hline 8 & I used to maintain good coordination among fellow workers. & 4.25 & .62 \\
\hline 9 & I actively participate in group discussions and work meetings & 4.21 & .66 \\
\hline 10 & I extend my sympathy and empathy to my co-workers when they are in trouble & 4.17 & .70 \\
\hline 11 & I am very passionate about my work & 4.16 & .86 \\
\hline 12 & My colleagues believe I am a high performance in my organization & 4.10 & .65 \\
\hline 13 & I could manage change in my job very well whenever the situation demands & 4.08 & .69 \\
\hline 14 & I can handle effectively my work team in the face of change & 4.01 & .71 \\
\hline 15 & I love to handle extra responsibilities & 3.96 & .87 \\
\hline 16 & I am very comfortable with job flexibility & 3.90 & .75 \\
\hline 17 & I use to cope well with organizational changes from time to time & 3.87 & .72 \\
\hline 18 & I used to lose my temper when faced with criticism from my team members & 2.51 & .94 \\
\hline & Employee's Performance & 4.09 & 0.72 \\
\hline
\end{tabular}


In addition, the relationship between Crisis Management with its dimensions; crisis preparedness and crisis prevention, and the dependent variable employee's performance was examined via Pearson Correlation as presented in Table 4. The results reveal that there is a significant positive correlation between employee's performance and crisis management $(\mathrm{r}=+0.328, \mathrm{p}=0.000)$, crisis preparedness $(\mathrm{r}=+0.274, \mathrm{p}=0.000)$ and crisis prevention $(\mathrm{r}=+0.291, \mathrm{p}=0.000)$. In addition, the results reveal that crisis management has significant positive strong correlation with crisis preparedness $(r=+0.906, p=0.000)$ and crisis prevention $(r=+0.778, p=0.000)$.

Table 4. Correlation Analysis

\begin{tabular}{llllll}
\hline Items & & $\begin{array}{l}\text { Employee's } \\
\text { Performance }\end{array}$ & $\begin{array}{l}\text { Crisis } \\
\text { Management }\end{array}$ & $\begin{array}{l}\text { Crisis } \\
\text { Preparedness }\end{array}$ & $\begin{array}{l}\text { Crisis } \\
\text { Prevention }\end{array}$ \\
\hline Employee's & Pearson Correlation & 1 & $.328^{* *}$ & $.274^{* *}$ & $.291^{* *}$ \\
Performance & Sig. (2-tailed) & & .000 & 0.000 & 0.000 \\
& $\mathrm{~N}$ & 268 & 268 & 268 & 268 \\
Crisis & Pearson Correlation & $.328^{* *}$ & 1 & $.906^{* *}$ & $.778^{* *}$ \\
Management & Sig. (2-tailed) & .000 & & 0.000 & 0.000 \\
& $\mathrm{~N}$ & 268 & 268 & 268 & 268 \\
Crisis & Pearson Correlation & $.274^{* *}$ & $.906^{* *}$ & 1 & $.439^{* *}$ \\
Preparedness & Sig. (2-t ailed) & .000 & 0.000 & & 0.000 \\
& $\mathrm{~N}$ & 268 & 268 & 268 & 268 \\
& Pearson Correlation & $.291^{* *}$ & $.778^{* *}$ & $.439 * *$ & 1 \\
Crisis Prevention & Sig. (2-tailed) & .000 & 0.000 & 0.000 & 268 \\
& $\mathrm{~N}$ & 268 & 268 & 268 & 260 \\
\hline
\end{tabular}

For the purpose of examining H1, which assumes that crisis management as the whole independent variable has a significant impact on employee's performance, a simple regression was performed. The output of the model summary of the simple regression for forecasting the independent variables being the most significant on Employees' Performance. Table 5. indicates that R Square $=0.108$ which mean that crisis management is explaining $10.8 \%$ of Employee's Performance variance. In addition, table 5 shows that Crisis Management has a significant impact on is participating significantly on Employee's Performance $(p=0.000$; Std. coefficients = 0.328 ) with mean of probability equal to $32.8 \%$. Therefore, Crisis Management $(p=0.000)$ factor has a significant impact on the dependent variable (Employee's Performance) since the predictive power (p-values) is $<0.05$ (PALLANT, 2005). As a result; $\mathrm{H} 1$ is accepted.

Table 5. Simple Regression Analysis Result: Predicting Employee's Performance

\begin{tabular}{|c|c|c|c|c|c|c|}
\hline \multirow[t]{2}{*}{ Model (1) } & \multicolumn{2}{|c|}{$\begin{array}{l}\text { Unstandardized } \\
\text { Coefficients }\end{array}$} & \multirow{2}{*}{$\begin{array}{l}\text { Standardized } \\
\text { Coefficients } \\
\text { Beta }\end{array}$} & \multirow[t]{2}{*}{$\mathbf{T}$} & \multirow[t]{2}{*}{ Sig } & \multirow[t]{2}{*}{ R Square } \\
\hline & $\mathrm{B}$ & Std. Error & & & & \\
\hline (Constant) & 3.374 & 0.129 & & 26.171 & 0.000 & \\
\hline CM & 0.204 & 0.036 & 0.328 & 5.668 & 0.000 & .108 \\
\hline
\end{tabular}

For the aim of testing the hypotheses H1a and H1b, the impact of Crisis Preparedness and Crisis Prevention dimensions on the Employee's Performance was tested via using the multiple regressions on these two dimensions as provided in Table 6 . The results indicate that $\mathrm{R}$ Square $=0.111$ which mean that independent dimensions Crisis Preparedness and Crisis Prevention are explaining 11.1\% of Employees' Performance variance. Table 6 it shows that $(\mathrm{F}$ test $=16.529$; at Sig. $=0.000)$ which indicates the strong significant relationship between the Employee's Performance as Dependent variable and the Independent dimensions. The results of coefficients in Table 6 reveal that Crisis Preparedness and Crisis Prevention have a significant impact on the Employees' Performance since their significant level ( $\mathrm{Sig}=0.005$ and 0.001$)$ is less than 0.05. Consequently, Hypotheses H1a and H1b are accepted. 
Table 6. Multiple Regression Analysis Result

\begin{tabular}{|c|c|c|c|c|c|c|c|}
\hline \multirow[t]{2}{*}{ Model } & \multicolumn{2}{|c|}{$\begin{array}{l}\text { Unstandardized } \\
\text { Coefficients }\end{array}$} & \multirow{2}{*}{$\begin{array}{c}\begin{array}{c}\text { Standardized } \\
\text { Coefficients }\end{array} \\
\text { Beta }\end{array}$} & \multirow[t]{2}{*}{$\mathbf{T}$} & \multirow[t]{2}{*}{ Sig } & \multirow[t]{2}{*}{$\begin{array}{c}\mathbf{R} \\
\text { square }\end{array}$} & \multirow[t]{2}{*}{$\mathbf{F}$} \\
\hline & B & Std. Error & & & & & \\
\hline (Constant) & 3.325 & 0.138 & & 4.039 & 0.000 & .111 & 16.529 \\
\hline Crisis Preparedness & 0.080 & 0.029 & 0.181 & 2.806 & 0.005 & & \\
\hline Crisis Prevention & 0.139 & 0.042 & 0.211 & 3.280 & 0.001 & & \\
\hline
\end{tabular}

Dependent Variable: EP

\section{Discussion and Conclusion}

According to the findings, crisis management has a major effect on the efficiency of workers as an objective variable. Hypothesis H1 is confirmed by this result. This outcome is followed by Pop (2017), who said that crisis management could have a significant impact on workers, specifically if an organization employs inadequate tactics to reverse the situation. As such, crisis management must still be diligent and provide management with the ability to formulate effective methods that, considering unavoidable critical conditions, will motivate workers to step further.

The result of simple regression shows that the study establishes that crisis preparedness has a significant impact on employee's performance, which supports Hypothesis H1a. These findings are corroborated by Sharma et al. (2016), who affirmed that the success in the oil and gas industry significantly depends on the workers' capability to execute their roles effectively as planned. According to Sharma et al. (2016), oil and gas companies cannot achieve this access in the absence of strategic responses and the appropriate decision- making to mitigate the crisis. Moreover, Bundy et al. (2016) indicated that pre-crisis exercises should include sufficient planning that aligns the required resources to underpin the exercise. Therefore, the success of crisis preparedness is a function of adequate resource allocation (De Wolf, 2013). Employee's performance is enhanced when they realize that specific people are delegated with responsibilities to manage the crisis (Andrianopoulos, 2015). According to Jaques (2007), employee training through simulations is paramount, especially for persons that are not directly involved in the crisis management. This knowledge is self-assuring, which increases the performance.

The result of the regression model shows that crisis prevention has a significant impact on employee's performance thus, supports hypothesis H1b. The results of the regression model are in tandem with Boin et al. (2016), who affirmed that the use of technology in not just more effective than conventional approaches but rather offers the required technical support to employees, which enhances organization performance. According to Coombs (2014), when a vigilance system is put in place, it enhances the likelihood that crisis will be mitigated proficiently. The realization that the organization has the early warning equipment in itself enhances employee's performance since a crisis will not happen abruptly. Instead, it can be detected before it spirals out of control (Bujak \& Topolski, 2015). Crisis prevention starts with the capacity to identify, prioritize the issue, and make appropriate approaches to manage the impending crisis (Pangarkar, 2016). An elaborate strategy leaves employee working to the best of their abilities because they know nothing will be left to chance (Van Dooren, Bouckaert, \& Halligan, 2015).

It can be concluded that the contemporary condition is portrayed by quick changes that causes different sorts of emergency on hierarchical and worker execution. Based on the study findings, crisis management has a significant impact on employee's performance. In particular, crisis preparedness and crisis prevention affect the productivity of employees. When the oil and gas companies implement adequate level of crisis preparedness and prevention, the performance among employees would be more productive. Yet, the opposite is the truth. For oil and gas companies to achieve exponential success not only strategic response is needed but also appropriate decisions. The oil and gas companies can take advantage of technology when providing the needed support to employees to enhance organization performance.

\section{Future Research}

Future research should be directed towards understanding the effectiveness of corporate change in terms of mitigating eminent crises using a repository of current information and previous strategies. Moreover, future studies should investigate how companies can utilize Big Data to mitigate crisis before they become destructive physically. Concerning the issue of preparedness, future research should unravel how effective information channels and agile technology can help oil and gas companies neutralize a looming catastrophe before it becomes uncontrollable. In addition, future research should investigate the way early warning technology can be bolstered to ensure accuracy of detection and the right response based on how the crisis is interpreted. Ultimately, future 
research should concentrate more on finding diagnostic capabilities that not only display accurate precision, but also incorporate intuitive capabilities to help the risk management personnel rein in on the exact spot and neutralize the anomaly.

\section{Recommendations}

The aim of this study was to examine the impact of crisis management on employee's performance in the Yemeni oil and gas industry. The outcomes of the study confirm the impact of two dimensions of crisis management on employee's performance, which include preparedness and crisis prevention. Accordingly, recommendations were provided as follows:

- The organization should be equipped with the right tools, especially for simulating crisis management and having employees understand how to address an eventuality.

- Crisis preparedness should entail determining how information is relayed to employees, especially those serving in designated crisis management groups.

- Risk analysis should incorporate testing as an integral aspect of planning for any occurrence. In this respect, it is necessary the HR unit to simulate crises to evaluate the proficiency of communication channels.

- Constant improvements should be based on continuous practice, where drills are conducted to measure progress.

- The communication process should not just promote divergent opinions but should be from all fronts.

- Companies have the prerogative to undertake a cautious selection of the crisis resolution personnel such as a spokesperson rep.

- Organizations should implement the right technology that relays underlying faults before degenerating into a crisis. This can help close examination of the anomaly, which is, then remediate beforehand.

- Before trying to mitigate a crisis, the involved personnel should screen the problem and plan based on the review in containing the crisis.

- To minimize high casualties, employees should be taught how to manage tension.

- The organization should install communication units or structures and ensure employees are trained meticulously based on mockups.

- The organization should ensure crisis plans are made available to the team of personnel tasked with managing the crisis.

- Oil and gas firms should encourage employees to formulate capabilities with the help of efficient diagnostic instruments of underlying crises. In turn, this will project some sense of management that will also enhance performance across the organization.

\section{References}

Andrianopoulos, A. (2015). Essential Steps for Crisis Management and Crisis Containment.

Anitha, J. (2014). Determinants of employee engagement and their impact on employee performance. International journal of productivity and performance management.

Bah, E. H., \& Fang, L. (2015). Impact of the business environment on output and productivity in Africa. Journal of Development Economics, 114, 159-171.

Bahadori, M., Khankeh, H. R., Zaboli, R., \& Malmir, I. (2015). Coordination in disaster: A narrative review. International Journal of Medical Reviews, 2(2), 273-281.

Bilić, I., Pivčević, S., \& Čevra, A. (2017). Crisis Management in Hotel Business-Insights from Croatia. Communication Management Review, 2(02), 100-118.

Boin, A., Stern, E., \& Sundelius, B. (2016). The politics of crisis management: Public leadership under pressure. Cambridge University Press.

Bujak, A., \& Topolski, M. (2015, April). Concept of a Telematics System Model in Crisis Management. In International Conference on Transport Systems Telematics (pp. 180-187). Springer, Cham.

Bundy, J., Pfarrer, M. D., Short, C. E., \& Coombs, W. T. (2017). Crises and crisis management: Integration, interpretation, and research development. Journal of management, 43(6), 1661-1692.

Christensen, T., Lægreid, P., \& Rykkja, L. H. (2016). Organizing for crisis management: Building governance 
capacity and legitimacy. Public Administration Review, 76(6), 887-897.

Comyns, B. (2016). Determinants of GHG reporting: An analysis of global oil and gas companies. Journal of business ethics, 136(2), 349-369.

Coombs, W. T. (2014). Ongoing crisis communication: Planning, managing, and responding. Sage Publications.

Crandall, W. R., Parnell, J. A., \& Spillan, J. E. (2013). Crisis management: Leading in the new strategy landscape. Sage Publications.

Cronin, J. K. (2015). Influencing crisis management success outcomes. Empowering Readiness. DOI: 10.1016/j.lisr.2014.09.003.

De Wolf, D. (2013). Crisis communication failures: The BP case study. International Journal of Advances in Management and Economics, 2(2), 48-56.

Dörry, S., \& Schulz, C. (2018). Green financing, interrupted. Potential directions for sustainable finance in Luxembourg. Local Environment, 23(7), 717-733.

Edwin, A. (2015). Training and development in the Oil and Gas Industry. Journal of Business Administration and Management Sciences Research, 4(9), 197-207.

Eisner, E., Bucci, S., Berry, N., Emsley, R., Barrowclough, C., \& Drake, R. J. (2019). Feasibility of using a smartphone app to assess early signs, basic symptoms and psychotic symptoms over six months: A preliminary report. Schizophrenia research, 208, 105-113.

Hernantes, J., Rich, E., Laugé, A., Labaka, L., \& Sarriegi, J. M. (2013). Learning before the storm: Modeling multiple stakeholder activities in support of crisis management, a practical case. Technological Forecasting and Social Change, 80(9), 1742-1755.

Iqbal, N., Anwar, S., \& Haider, N. (2015). Effect of leadership style on employee performance. Arabian Journal of Business and Management Review, 5(5), 1-6.

Jackson, R. L. (2017). Pre-Crisis Leadership: An Exploration of Crisis Prevention for Global Leaders with National Organizations in Zimbabwe (Doctoral dissertation, Indiana Institute of Technology).

Jaques, T. (2007). Issue management and crisis management: An integrated, non-linear, relational construct. Public relations review, 33(2), 147-157.

Jundt, D. K., Shoss, M. K., \& Huang, J. L. (2015). Individual adaptive performance in organizations: A review. Journal of Organizational Behavior, 36(S1), S53-S71.

Ek, K., \& Mukuru, E. (2013). Effect of motivation on employee performance in public middle level Technical Training Institutions in Kenya. International Journal of Advances in Management and Economics, 2(4), 7382.

Krejcie and Morgan Sampling Method. (2017, October 5). Retrieved from IN-TROH-SPECTIVE: http://in-trohspective.blogspot.com/2017/10/krejcie-and-morgan-sampling-method.html

Mangkunegara, A. A. P. (2016). The effect of transformational leadership and job satisfaction on employee performance. Universal Journal of Management, 4(4), 189-195. DOI: 10.13189/ujm.2016.040404.

Mehr, M. K., \& Jahanian, R. (2016). Crisis Management and Its Process in Organization. Mediterranean Journal of Social Sciences, 7(5 S1), 143.

Özdemir, L. (2010). The positive and negative effects of crisis on organizations: An application. A paper presented at Turgut Özal International Conference on Economics and Politics.

Pangarkar, N. (2016). A framework for effective crisis response. Journal of Organizational Change Management.

Pop, Ș. (2017). Prevention and crisis management. International Conference Knowledge-Based Organization, 23(1). 246-250. doi:10.1515/kbo-2017-0039

Pradhan, R. K., \& Jena, L. K. (2017). Employee performance at workplace: Conceptual model and empirical validation. Business Perspectives and Research, 5(1), 69-85. 
Raufflet, E., Cruz, L. B., \& Bres, L. (2014). An assessment of corporate social responsibility practices in the mining and oil and gas industries. Journal of Cleaner production, 84, 256-270.

Renschler, L. A., Terrigino, E. A., Azim, S., Snider, E., Rhodes, D. L., \& Cox, C. C. (2016). Employee Perceptions of Their Organization's Level of Emergency Preparedness Following a Brief Workplace Emergency Planning Educational Presentation. Safety and health at work, 7(2), 166-170.

Robescu, O., \& Iancu, A. G. (2016). The effects of motivation on employees performance in organizations. Valahian Journal of Economic Studies, 7(2), 49-56.

\section{Copyrights}

Copyright for this article is retained by the author(s), with first publication rights granted to the journal. This is an open-access article distributed under the terms and conditions of the Creative Commons Attribution license (https://creativecommons.org/licenses/by-sa/4.0/). 